\title{
The Performance of a Fixed-Bed Anaerobic Bioreactor Using Sulfate-Reducing Bacterial Consortium from Sikidang Crater Sediments
}

\author{
Andriyanto ${ }^{1,2}$, Wahyu Wilopo ${ }^{3}$, and Endah Retnaningrum ${ }^{2, *}$ \\ ${ }^{1}$ Study Program of Biology Education, STKIP YPM Bangko, Jl. Jenderal Sudirman Km. 02 Bangko, Jambi 37311, Indonesia \\ ${ }^{2}$ Faculty of Biology, Universitas Gadjah Mada, Jl. Teknika Selatan, Sekip Utara, Yogyakarta 55281, Indonesia \\ ${ }^{3}$ Geological Engineering Department, Faculty of Engineering, Universitas Gadjah Mada, \\ Jl. Grafika No. 2, Bulaksumur, Yogyakarta 55281, Indonesia
}

* Corresponding author:

tel: $+62-274-580839$

email:endahr@ugm.ac.id

Received: April 18, 2019

Accepted: October 10, 2019

DOI: $10.22146 / \mathrm{ijc} .45164$

\begin{abstract}
This research explored the performance of a fixed-bed anaerobic bioreactor system (FBR) using sulfate-reducing bacteria (SRB) from the sediment of Sikidang Crater in Indonesia. Indonesian natural zeolite was used as an inert medium in this bioreactor system. This bioreactor performance was analyzed based on its sulfate reduction efficiency, $C u$ removal, $p H$ profile, SRB growth, and the changes in mineral composition of the zeolite surface. Based on a batch experiment, the FBR system was operated at $30^{\circ} \mathrm{C}$ with a hydraulic retention time (HRT) of 7 days using a zeolite dose of $100 \mathrm{~g} / \mathrm{L}$. After its operation, a large amount of SRB (up to $1.5 \times 10^{5} \mathrm{cells} / \mathrm{mm}^{2}$ ) was entrapped and presented in the zeolite. This bacterial consortium could reduce sulfate and copper by around $68 \%$ and $99.96 \%$, respectively. In addition, the $\mathrm{pH}$ value of the bioreactor changed to neutral, which indicated a good performance of the operation. The result of the Energy-Dispersive X-ray (EDX) confirmed that copper removal was caused by the formation of copper-sulfide precipitation. Mapping also revealed that both copper and sulfur were precipitated at the same location.
\end{abstract}

Keywords: FBR; SRB; natural zeolite; EDX; copper-sulfide

\section{- INTRODUCTION}

The elevated sulfate and metal content in acid mine drainage (AMD) can be very harmful to the environment [1-2]. AMD is formed when sulfide minerals in mine spoils react with water and oxygen $\left(\mathrm{H}_{2} \mathrm{O}\right.$ and $\left.\mathrm{O}_{2}\right)$ to produce acidic compounds that dissolve toxic waste containing metals and trace elements. Copper $(\mathrm{Cu})$ is a potentially toxic metal that is harmful to most organisms where its concentration in AMD is very high [3-4]. The toxicity of AMD could be reduced by conventional treatment techniques, such as ion-exchange, neutralization, and coagulation-precipitation [5]. However, these treatments require a large amount of chemicals, energy, and can be expensive.

Biological treatment using sulfate-reducing bacteria (SRB) has the potential to be used for the treatment of AMD [6]. The use of SRB has several advantages over conventional treatments as it is more efficient, relatively inexpensive, and more environmentally friendly [7]. SRB has the capability to reduce sulfate to sulfide, and then sulfide reacts with the dissolved metals forming insoluble metal precipitates [8].

The fixed-bed anaerobic bioreactor system is one of the faster anaerobic treatment methods of industrial wastewater. This system is a generally accepted in the industry due to its stability and resistance to AMD. Several researchers reported that the characters of the support medium greatly affect the performance of the anaerobic fixed-bed reactor [9-10]. The support medium provides a source of attachment for the bacterial biomass, acts as a bio-filtration bed, and helps prevent the washout of the biomass from the reactor. In addition, the SRBs attachment to the support medium promotes cell growth, a shorter generation time, greater products, and less inhibition products, and easier separation of the product and the medium [11]. 
Previous research explored the properties of various supporting media, such as polyvinyl alcohol gel beads, ceramic, polyethylene, clay, and activated carbon [12-14]. However, recent studies showed that zeolite had good potential if applied to the fixed-bed anaerobic bioreactor system [15]. In addition, zeolite materials can be obtained in very large quantities from some areas of Indonesia [16]. Therefore, the utilization of indigenous bacterial consortium and Indonesian natural zeolite in the FBR system was very effective. These components were very suitable to be applied to tropical environments in Indonesia, and could also reduce the costs during the application process.

Previous investigations have also reported that the volume and the particle size of the support medium influenced the performance of the bioreactor [17-21]. This performance also depends on the hydraulic residence time (HRT). A long HRT induces high sulfate reduction efficiencies and complete oxidation of the electron donor used. However, a short HRT may decrease the time available for the SRB to metabolize the substrate perfectly and cause biomass washout from the bioreactor [22].

Sediment from Sikidang Crater, located in Dieng Highland, Banjarnegara, Central Java, has unique physicochemical properties, such as $\mathrm{pH}$ values in the range of 2 to 3 , a temperature between $30^{\circ} \mathrm{C}$ and $100{ }^{\circ} \mathrm{C}$, and high sulfate content. Therefore, SRB isolated from Sikidang Crater may potentially be applied to treat AMD [23]. It is important to evaluate the activity of SRB from the Sikidang Crater sediment attached to the Indonesian natural zeolite medium (as their inert support) within the FBR system. The purpose of this research was to explore the performance of the FBR using the consortium of SRB from the Sikidang Crater sediment using Indonesian natural zeolite as the medium. The performance of the bioreactor was analyzed based on the sulfate reduction efficiency, $\mathrm{Cu}$ removal, $\mathrm{pH}$ profile, SRB growth, and the changes in mineral composition of the zeolite surface.

\section{- EXPERIMENTAL SECTION}

\section{Materials}

The SRB consortium used in this experiment was isolated from Sikidang Crater, Dieng Highland, Banjarnegara district in Central Java. The culture was incubated in a glass bottle with Postgate B medium at $30{ }^{\circ} \mathrm{C}$. The medium consisted of the following nutrients (in g/L): $8 \mathrm{~mL} \mathrm{NaC}_{3} \mathrm{H}_{5} \mathrm{O}_{3}, 1.0 \mathrm{MgSO}_{4}, 0.5 \mathrm{NH}_{4} \mathrm{Cl}, 1.0$ $\mathrm{KH}_{2} \mathrm{PO}_{4}, 0.1 \mathrm{FeSO}_{4}, 0.5 \mathrm{C}_{6} \mathrm{H}_{8} \mathrm{O}_{6}, 0.1 \mathrm{C}_{6} \mathrm{H}_{12} \mathrm{O}_{6}, 0.1 \mathrm{CaCl}_{2}$, $0.5 \mathrm{Na}_{2} \mathrm{SO}_{4}, 0.1$ yeast extract [24]. Previously, this medium was adjusted to $\mathrm{pH} 5$ and aerated with nitrogen gas to regulate anaerobic conditions. Every 3 weeks, $20 \%$ of the SRB culture in the flask was replaced by fresh medium. After two months, a high density bacterial consortium was obtained. Modified Postgate B medium was used for batch and continuous culture experiments. In this experiment, $0.1 \mathrm{~g}$ of $\mathrm{FeSO}_{4}$ was excluded from the media to allow for the assessment of the $\mathrm{Cu}$ metals precipitation. This $\mathrm{FeSO}_{4}$ was replaced by $0.078 \mathrm{~g}$ of $\mathrm{CuSO}_{4} \cdot 5 \mathrm{H}_{2} \mathrm{O}$ and $2.56 \mathrm{~g}$ of $\mathrm{Na}_{2} \mathrm{SO}_{4}$, which were added to the medium. The concentration of sulfate and copper $(\mathrm{Cu})$ in the modified medium was $3000 \mathrm{ppm}$ and $20 \mathrm{ppm}$, respectively.

The natural zeolite used as an inert support for the SRB was collected from a zeolite mine located in the Gunungkidul district, Yogyakarta, Indonesia. The zeolite chemical composition (in \% w/w) consists of: $\mathrm{SiO}_{2}$ 86.3\%; $\mathrm{Al}_{2} \mathrm{O}_{3}$ 13.7\%; $\mathrm{Fe}_{2} \mathrm{O}_{3} 2.4 \% ; \mathrm{CaO}$ 2.3\%; $\mathrm{MgO} 0.4 \%$; $\mathrm{Na}_{2} \mathrm{O}$ 1.7\%; and $\mathrm{K}_{2} \mathrm{O} 1.8 \%$. The mineral composition consists of clinoptilolite, mordenite, and montmorillonite. The diameter, surface area, pore volume, and pore size of the zeolite were $2-5 \mathrm{~mm}, 20.0 \mathrm{~m}^{2} / \mathrm{g}, 12.4 \mathrm{~mL} / \mathrm{g}$, and $23.8 \AA$, respectively. Impurities in the zeolite were removed by washing twice and soaking in deionized water for $24 \mathrm{~h}$ at $30^{\circ} \mathrm{C}$. After that, the zeolite was dried for $24 \mathrm{~h}$ at $80{ }^{\circ} \mathrm{C}$ and used as a support for the immobilization of SRB consortium cultures for both batch and continuous experiments [16].

\section{Instrumentation}

Centrifuged (Eppendorf, 5810R) apparatus was used for the separation of bacterial cells and medium. For the analysis of sulfate and manganese removal, a spectrophotometer (Shimadzu UV-1601) and an Atomic Absorption Spectroscopy (AAS) apparatus (Hitachi, Z-2000) were used, respectively. The decrease in $\mathrm{pH}$ values in the bioreactor was measured using a $\mathrm{pH}$ meter (Metrohm). The characteristics of the biofilm and the copper interacted on the zeolite surface were

Andriyanto et al. 
observed using Scanning Electron Microscope - Energy Dispersive X-ray (SEM-EDX) (JEOL JSM-T300).

\section{Procedure}

\section{SRB cultures}

The SRB consortium used in this study was isolated from the Sikidang Crater sediment. About $50 \mathrm{~g}$ of wet sediment was transferred to a $1 \mathrm{~L}$ flask, which was then completely filled with Postgate B medium, sealed with a rubber stopper, and incubated in the dark at $30^{\circ} \mathrm{C}$. After 7 days of incubation, $200 \mathrm{~mL}$ of the culture was inoculated into a fresh medium at $30^{\circ} \mathrm{C}$ for 7 days. This sub-culturing into the fresh medium was conducted repeatedly over 3 weeks to maintain a high density of SRB in culture.

\section{Anaerobic batch experiment}

The SRB consortium was inoculated into $450 \mathrm{~mL}$ of the modified Postgate $B$ medium at anaerobic conditions. Five different doses of zeolite $(20,40,60,80$, and $100 \mathrm{~g} / \mathrm{L})$ was added to each batch of SRB culture and incubated at $30{ }^{\circ} \mathrm{C}$ for 14 days. This batch reactor setup was conducted in Erlenmeyer flasks, which were incubated in the incubator. During incubation, samples were collected at $0,1,3,7,10$, and 14 days for further analysis. There were three replications for each of the treatment groups. Anaerobic batch experiments were carried out to determine the optimal zeolite dose and HRT for the anaerobic continuous experiment, which uses a fixed-bed anaerobic bioreactor.

\section{Anaerobic continuous experiment}

A continuous laboratory-scale fixed-bed anaerobic bioreactor system was used in this experiment, with Indonesian natural zeolite as supporting material. The bioreactors used in this study were constructed using plastic tubes with an internal diameter of $7 \mathrm{~cm}$ and a length of $67 \mathrm{~cm}$ (Fig. 1). The adherence of the active SRB biofilm onto the natural zeolite was carried out over one month. For this purpose the Postgate medium was inoculated with SRB consortium culture containing $\sim 3 \times 10^{5}$ cells $/ \mathrm{mL}$ $(20 \% \mathrm{v} / \mathrm{v})$ [25]. The modified Postgate B medium was used as a synthetic AMD and was fed into the reactor at a rate of $15.34 \mathrm{~mL} / \mathrm{h}$. This bioreactor was then operated with the optimal conditions (temperature, HRT, and zeolite dose) obtained from the batch experiment.

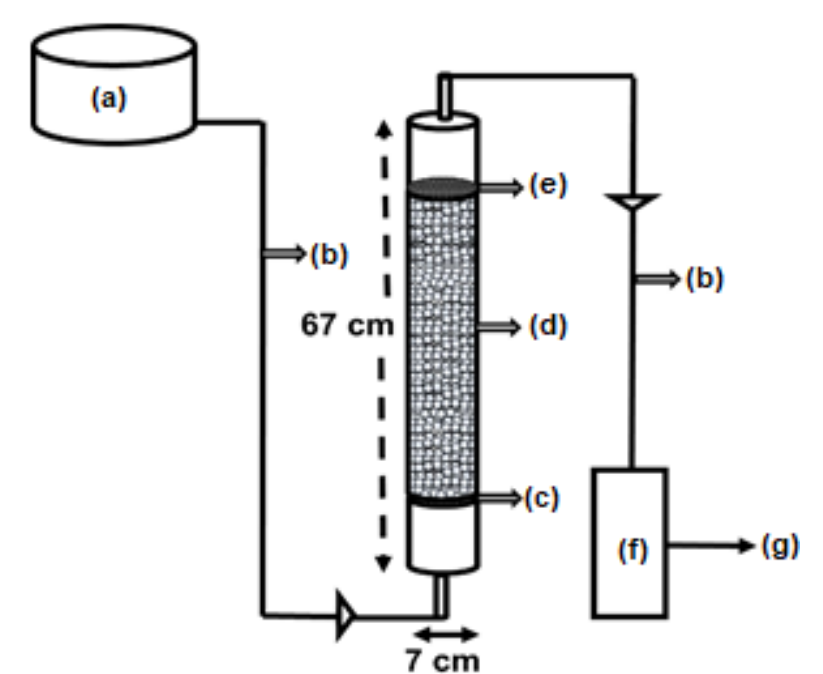

Fig 1. The experimental design of continuous laboratory-scale of the fixed-bed anaerobic bioreactor system: (a) synthetic AMD, (b) connector pipe, (c) stainless steel sieve and filter, (d) SRB biofilm on zeolite surface, (e) filter, (f) outlet, (g) measurements

\section{Chemical analysis}

At several time intervals $(0,1,3,7,10,14$ days), $10 \mathrm{~mL}$ of a sample from both the batch experiment and continuous experiments were collected using a syringe. These samples were then centrifuged at $5000 \mathrm{rpm}$ at $4{ }^{\circ} \mathrm{C}$ for $15 \mathrm{~min}$ to obtain the cell-free supernatant. The supernatant was analyzed for their sulfate and copper metal concentrations. Sulfate concentration was analyzed based on the turbid metric method at a wavelength of $420 \mathrm{~nm}$ using a spectrophotometer (Shimadzu UV-1601) [25]. To determine the dissolved copper concentration, the supernatant was acidified with $\mathrm{HNO}_{3}$ and measured through AAS using a spectrometer (Hitachi Z-2000). The $\mathrm{pH}$ samples were measured immediately without centrifugation using a $\mathrm{pH}$ meter (Metrohm). In addition, the $\mathrm{pH}$ during the operation of the bioreactor was also measured.

\section{Characterization of developed SRB population}

The SRB consortium in the batch experiments was taken and characterized during both the planktonic phase and the biofilm phase (after 1, 3, 7, 10, and 14 days). Up to $1 \mathrm{~mL}$ of the consortium was taken for the planktonic phase, which was diluted with $9 \mathrm{~mL}$ sterile water. Whereas, samples of the biofilm phase were collected by 
scraping $1 \mathrm{~cm}^{2}$ of the zeolite surface using a sterile scraped and then suspended in $10 \mathrm{~mL}$ sterile water. The number of SRB consortium were then analyzed in the three-tube Most Probable Number assay with serial dilution [24].

\section{EDX analysis}

EDX is a chemical characterization technique used in conjunction with scanning electron microscopy (SEM). JEOL JSM-T300 (environmental scanning electron microscope interfaced with EDAX digital controller) was used. Zeolite (mounted on an aluminum stub that had been covered by colloidal graphite and carbon tape) was placed in the SEM and analyzed under low vacuum mode by tilting to an angle of $15^{\circ}$ toward the X-ray gun. A working distance of $10 \mathrm{~mm}$ and an accelerating voltage of $15 \mathrm{keV}$ were used for all EDX analyses, and the EDX spectra were collected over $270 \mathrm{sec}$ (i.e., live count time) [26].

\section{Statistical analysis}

The data were analyzed statistically using SPSS (v. 20, IBM). A p-value of less than 0.05 was considered to be significantly different. The data were evaluated using oneway ANOVA, followed by a post-hoc Duncan test to analyze the significance of differences across the treatments.

\section{- RESULTS AND DISCUSSION}

\section{Effect of Natural Zeolite Doses on the pH Change, Sulfate Reduction and Cu Precipitation in the Batch Experiment}

For the batch experiment, the effects of zeolite dosage on $\mathrm{pH}$, the removal of both sulfate and $\mathrm{Cu}$ over time are presented in Fig. 2. Sulfate removal, $\mathrm{pH}$ change, and $\mathrm{Cu}$ removal are sequential processes that developed during SRB metabolism. The SRB oxidize simple organic compounds, such as lactate, acetate, butyrate, and other fermentation products under anaerobic conditions using sulfate as a terminal electron acceptor. The sulfate is then reduced to hydrogen sulfide and bicarbonate. Hence, this bicarbonate neutralizes the acidity of the medium and produces hydrogen sulfide, which reacts with dissolved copper to form insoluble copper sulfides (CuS) [27].

The zeolite doses had significant effects on SRB activities $(\mathrm{p}<0.05)$. The optimal condition was observed in a zeolite dose of $100 \mathrm{~g} / \mathrm{L}$. These observations were consistent with previous investigations [16]. For other bacterial groups, zeolite also plays a role as an adsorbent media in the batch reactor, causing an increase in $\mathrm{NH}_{4}{ }^{-}$ $\mathrm{N}$ adsorption capacity that impacts on nitrogen transformation and microbial abundance [28]. Another study reported that a moving bed biofilm reactor (MBBR) using simultaneous bacteria nitrification and denitrification (with zeolite powder-based polyurethane sponges as bio-carriers) could remove $10 \%$ more total $\mathrm{N}$ in wastewater compared to conventional MBBR [29]. Zeolite also increased methane production by 32 to $97 \%$ in the hydrothermal liquefaction processes. Whereas, in laboratory scale investigations over 60 days, swine manure was digested anaerobically using a natural zeolite dose of $40 \mathrm{~g} / \mathrm{L}$ that produced the highest amount of methane [30].

During the experiments, the removal of sulfate was followed by an increase in $\mathrm{pH}$ and a decrease in $\mathrm{Cu}$ concentration. The zeolite increased the $\mathrm{pH}$ value significantly, which reached a neutral condition in 7 days of operation. Moreover, the $\mathrm{Cu}$ concentration decreased significantly after 1 day of operation ( $\mathrm{p}<$ 0.05 ), and its removal efficiency was around $99.96 \%$. The faster $\mathrm{Cu}$ removal after $5 \mathrm{~min}$ of operation was also reported by Janyasuthiwong et al. who found removal efficiencies of more than $95.0 \%$ [31]. A similarly high $\mathrm{Cu}$ removal rate of around $99 \%$ was also reported by other researchers [32].

\section{Effect of Natural Zeolite Doses on the Growth of SRB Consortium in the Batch Experiment}

It was demonstrated that the SRB consortium developed planktonic and biofilm phases in the bioreactor system. As shown in Fig. 3, the bacterial cell number was higher with zeolite addition than without ( $\mathrm{p}$ $<0.05)$. This difference was caused by the growth of the biofilm phase, which was shorter compared to the planktonic phase. In addition, the biofilm phase had a shorter lag phase that was observed within 1 day of incubation. In comparison, the planktonic phase was observed at 7 days of incubation. Therefore, the SRB consortium in the biofilm phase was more adaptive to the new environment and the stressful conditions [33]. This phenomenon was observed in previous research 

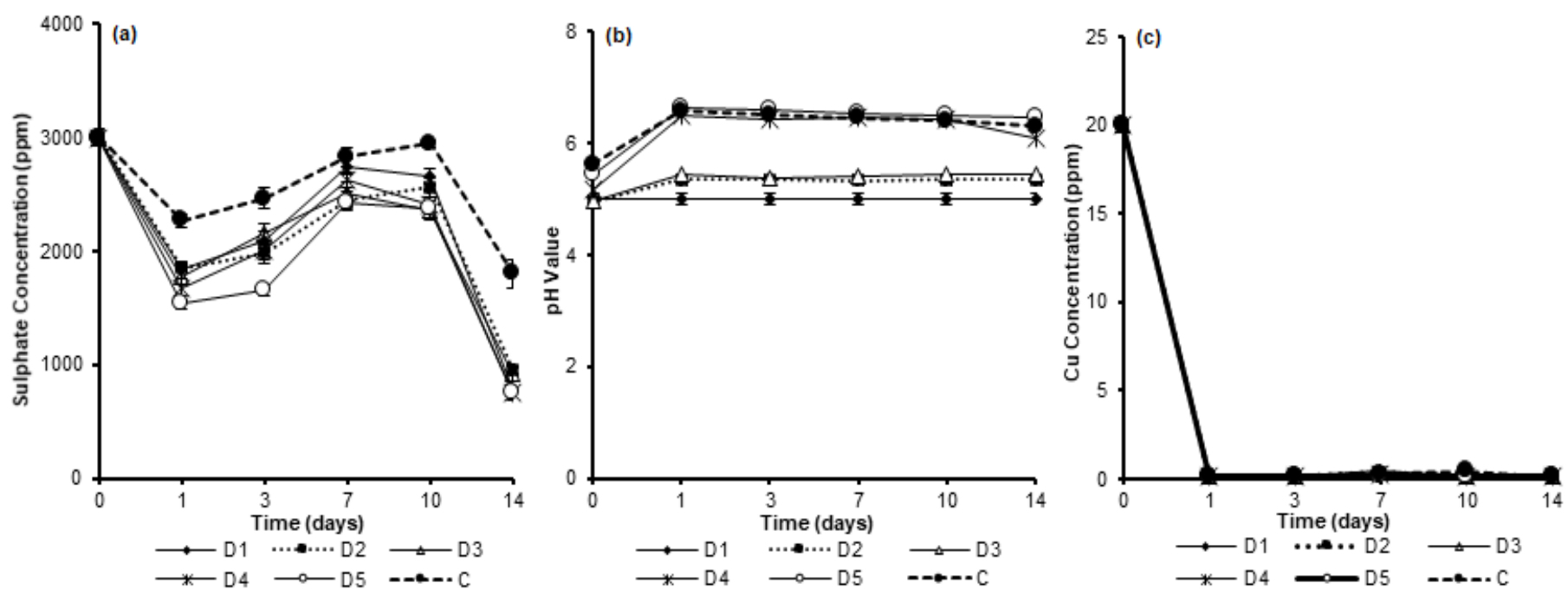

Fig 2. The effect of different zeolite doses on the SRB activity at batch experiment as function of time: (a) the removal of sulfate, (b) change in $\mathrm{pH}$ value, (c) the removal of $\mathrm{Cu}$. The treatments D1, D2, D3, D4, and D5 represent zeolite at doses of 20,40,60, 80, and $100 \mathrm{~g} / \mathrm{L}$, respectively, whereas the control (C) was without zeolite addition
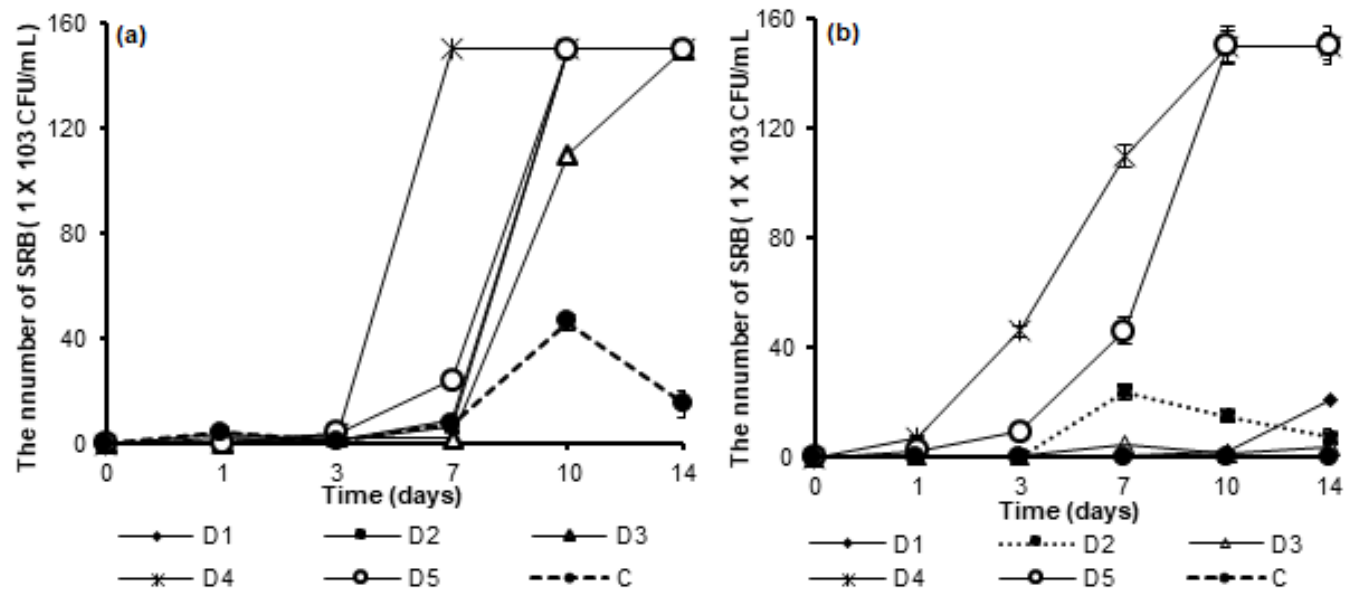

Fig 3. The effect of different zeolite doses on the growth of SRB consortium in the batch experiments, (a) planktonic phase, (b) biofilm phase. The treatments of D1, D2, D3, D4, and D5 represents zeolite doses of 20, 40, 60, 80, and $100 \mathrm{~g} / \mathrm{L}$, respectively, whereas the control $(\mathrm{C})$ was without zeolite addition

investigating the formation of the biofilm phase with Streptococcus mutans, which was shorter than the planktonic phase. This was due to microorganisms that formed biofilm had several favorable responses in the system. Hence, the microorganisms had higher active biomass, tolerance to toxic compounds, and greater plasmid stability of microbial genes [34].

A large amount of the bacterial biomass was entrapped and attached to the zeolite surface as a biofilm. The highest density of cells was measured at $1.5 \times 10^{5} \mathrm{cells} / \mathrm{mm}^{2}$. This highest number was observed at zeolite doses of 80 and
$100 \mathrm{~g} / \mathrm{L}$. However, a zeolite dose of $100 \mathrm{~g} / \mathrm{L}$ was more adaptive compared with a zeolite dose of $80 \mathrm{~g} / \mathrm{L}$.

\section{The Performance of Fixed-bed Anaerobic Bioreactor Experiments}

In the continuous experiments, the $\mathrm{pH}$ value and copper and sulfate concentrations were measured at various times over a period of 7 days under optimum conditions $\left(30^{\circ} \mathrm{C}\right)$. As demonstrated in Fig. 4, the performance of the bioreactor treatment with a zeolite dose of $100 \mathrm{~g} / \mathrm{L}$ was more effective compared to the 

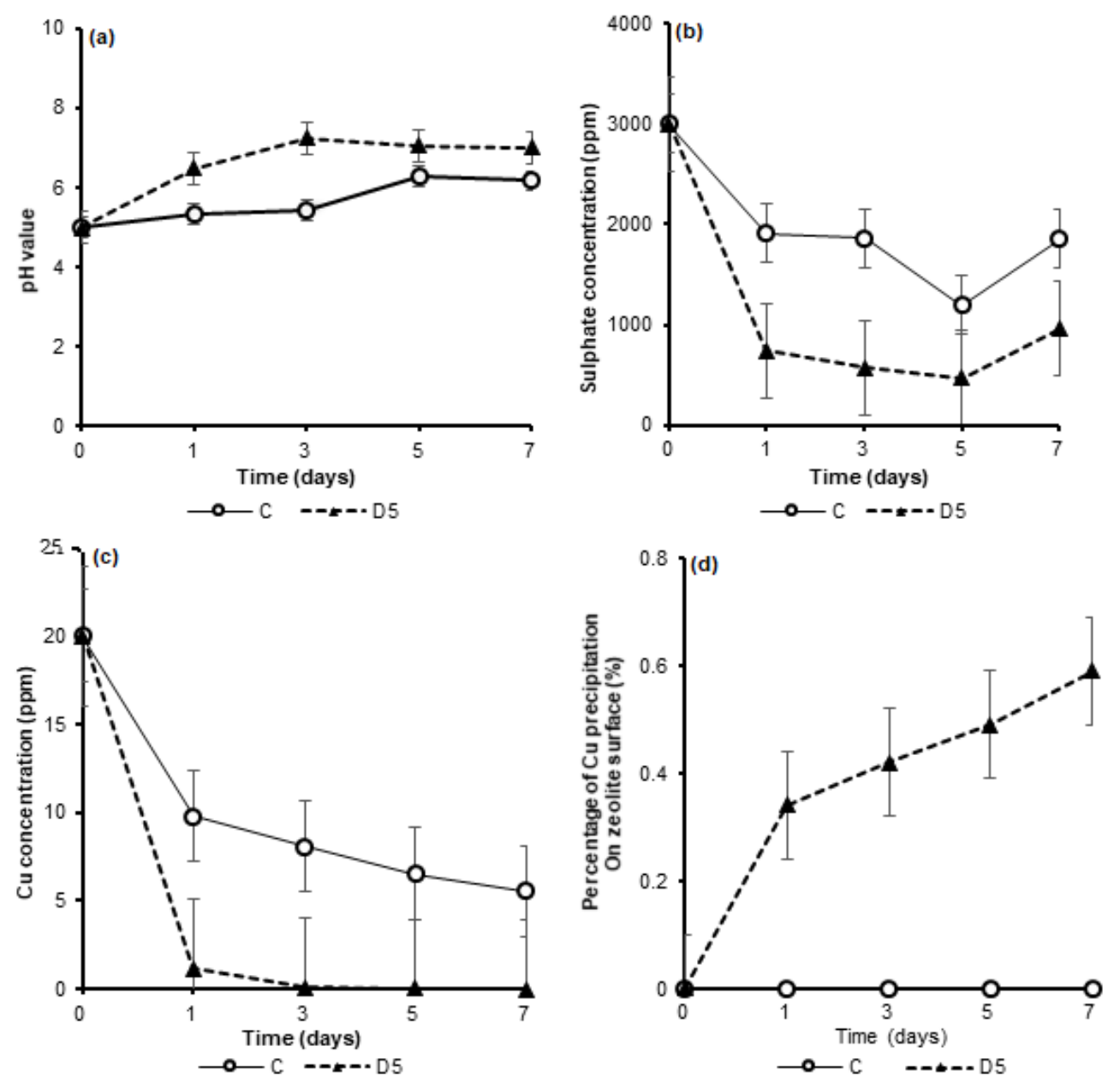

Fig 4. The performance of the fixed-bed anaerobic bioreactor for the treatment of synthetic AMD using the sulfate reducing bacteria consortium from Sikidang Crater sediments $\left(1.5 \times 10^{5} \mathrm{cells} / \mathrm{mm}^{2}\right)$ and a natural zeolite dose of $100 \mathrm{~g} / \mathrm{L}$ with a hydraulic retention time of 7 days at $30{ }^{\circ} \mathrm{C}$. (a) The change of $\mathrm{pH}$ values, (b) sulfate concentration, (c) $\mathrm{Cu}$ concentration, (d) the percentage of $\mathrm{Cu}$ precipitation on the zeolite surface at a dose of $100 \mathrm{~g} / \mathrm{L}$. D5: zeolite dose of $100 \mathrm{~g} / \mathrm{L}$, and $\mathrm{C}$ : without zeolite addition

bioreactor without zeolite as a control for all parameters $(\mathrm{p}<0.05)$.

After 7 days of operation, the sulfate concentration of the reactor treatment with a zeolite dose of $100 \mathrm{~g} / \mathrm{L}$ declined sharply to $920 \mathrm{ppm}$ with $68 \%$ removal efficiency, whereas the sulfate concentration of reactor treatment without zeolite was 1848 ppm with $38.4 \%$ removal efficiency. These sulfate reduction processes generated hydrogen sulfide and bicarbonate. The bicarbonate neutralizes the acidity of the medium in the bioreactor [25].

The $\mathrm{pH}$ values measured after 7 days of operation with a zeolite dose of $100 \mathrm{~g} / \mathrm{L}$ and without zeolites were 7.0 and 6.61, respectively. In these reactors, hydrogen sulfide reacts with dissolved copper to form insoluble $\mathrm{CuS}$. Consequently, the $\mathrm{Cu}$ concentrations were diminished. The $\mathrm{Cu}$ concentration of the reactor treatment with a zeolite dose of $100 \mathrm{~g} / \mathrm{L}$ was almost completely diminished (99.96\%). On the other hand, in the reactor treatment without zeolite, $\mathrm{Cu}$ the concentration was reduced by $72.35 \%$. These decreases of $\mathrm{Cu}$ in the aqueous solution were followed by the accumulation of $\mathrm{Cu}$ in the biofilm surface. The $\mathrm{Cu}$ accumulation process on the zeolite surface was dominated by metalloid precipitation caused by the activities of the SRB [35]. In addition, the biofilm extracellular polymeric substances of SRB could entrap the metal sulfide particles [36]. 
A previous study reported that acid wastewaters at a sulfate loading rate $88 \mathrm{mg} / \mathrm{L} / \mathrm{h}$ containing $100 \mathrm{mg} / \mathrm{L} \mathrm{Cu}$ could be remediated by SRB in a fixed-bed anaerobic bioreactor with a metal removal of 94\% [37]. The tolerance to heavy metals, $\mathrm{pH}$ value, heavy metals, and sulfate removal of immobilized SRB beads was also reported to be significantly enhanced compared with planktonic SRB when the bioreactor was fed with acidic medium containing multiple metals [38]. Another study reported that Indonesian natural zeolite was good inert material for SRB in a laboratory-scale down-flow fluidized-bed reactor. After 9 days of operation, the $\mathrm{pH}$ changed to neutral, and sulfate and manganese reduced to $23 \%$ and $15.4 \%$, respectively [16].
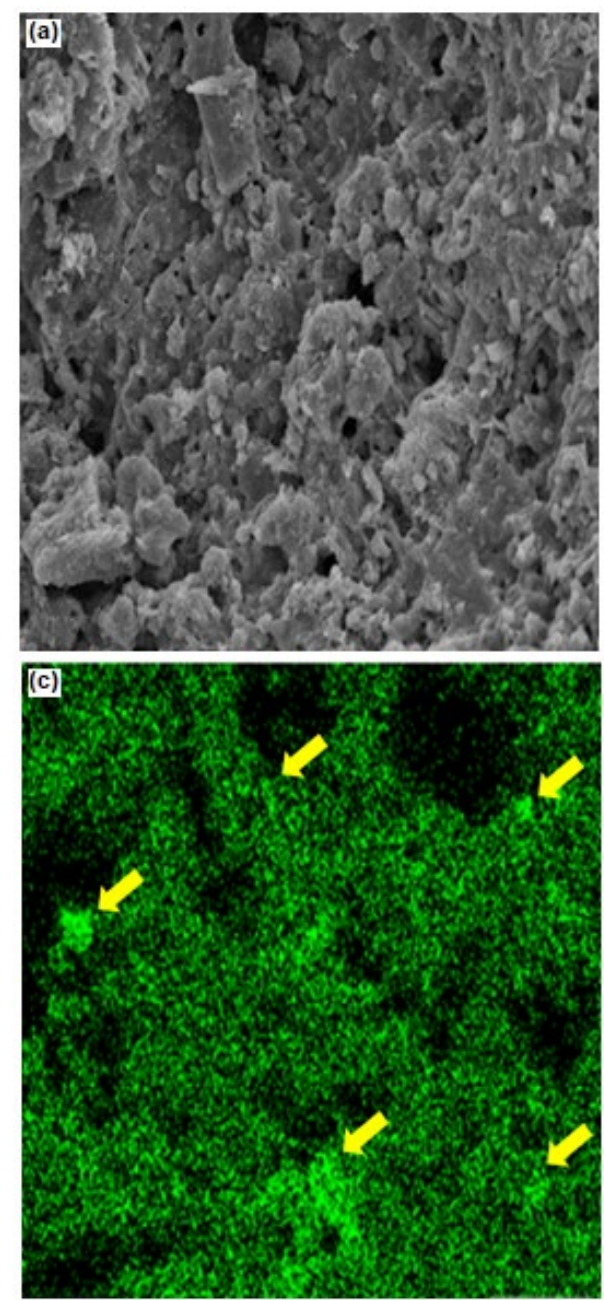

\section{SEM-EDX Analysis}

The composition of the metal precipitates that were accumulated on the surface of zeolite in the bioreactor was determined by SEM-EDX (Fig. 5). The biofilm developed on the support material was investigated after 7 days of incubation. The analysis revealed that $\mathrm{Cu}$ was entrapped in both the biofilm and zeolite surface. This observation implies that the metal removal process mainly occurs via sulfide precipitation. The EDX spectra of spots on the zeolite surface revealed the predominance of copper and sulfur at the same precipitation location. This result proved that copper sulfide had been precipitated on the zeolite surface. In addition, this precipitation was confirmed by the results
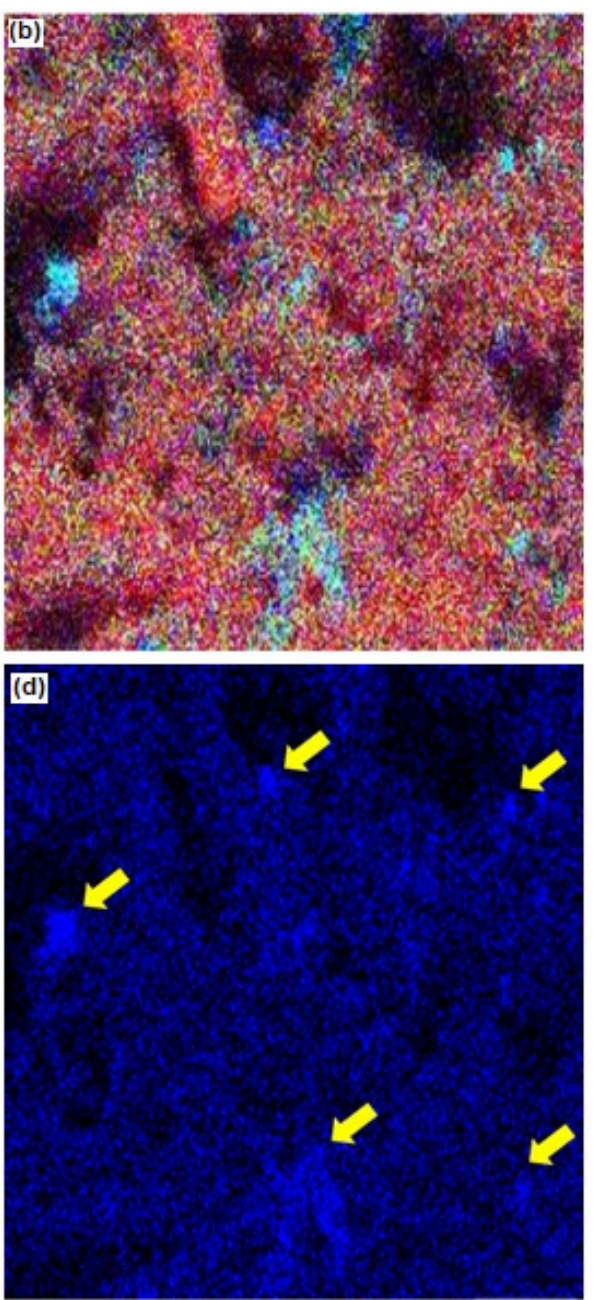

Fig 5. The biofilms developed on zeolites and the composition of their compounds and elements. (a) SEM image of the consortium of SRB biofilms, (b) EDX mapping image of CuS, (c) EDX mapping image of elemental Cu, (d) EDX mapping image of elemental $\mathrm{S}$. The yellow arrows indicate solid $\mathrm{CuS}$ precipitants 
of the SEM mapping image of copper-sulfides (CuS) in the SRB biofilms consortium. The CuS was precipitated and accumulated on the zeolite surface.

As reported previously, bacterial biofilms could decrease heavy metal pollution in wastewater by several mechanisms, including biosorption, precipitation as sulfides or phosphates, and bacterial reductive precipitation [39]. Therefore, the precipitation process decreased the $\mathrm{Cu}$ concentration in the bioreactor. This precipitation was caused by the reaction between $\mathrm{Cu}$ and the sulfide produced by SRB. This $\mathrm{Cu}$ removal mechanism via $\mathrm{CuS}$ precipitation in the SRB biofilm was consistent with previous studies [40]. This precipitation was also reported to be an efficient method for separating toxic metals from wastewater due to the very low solubility of $\mathrm{CuS}$ [41].

\section{- CONCLUSION}

The optimal performance of the fixed-bed anaerobic bioreactor was obtained by operating at $30{ }^{\circ} \mathrm{C}$ with HRT over 7 days using SRB consortium from Sikidang Crater sediments and a zeolite dose of $100 \mathrm{~g} / \mathrm{L}$. The bioreactor could reduce sulfate and $\mathrm{Cu}$ concentrations by $68 \%$ and 99.96\%, respectively. The SRB biomass formed a biofilm on the zeolite surface. Based on the Energy-Dispersive Xray analysis (EDX), the $\mathrm{Cu}$ precipitate was in the form of CuS. In addition, EDX mapping of both $\mathrm{Cu}$ and $\mathrm{S}$ elements showed that they were precipitated at the same location in the biofilm section.

\section{- ACKNOWLEDGMENTS}

The authors acknowledge the financial support by the KEMENRISTEK DIKTI Indonesia with the Research Implementation Letter No: 663/UN1-P.III/LT/DITLIT/2016. We also thank the Laboratorium Penelitian Pusat Terpadu, Universitas Gadjah Mada, Yogyakarta for the SEM-EDX analysis.

\section{- REFERENCES}

[1] Jamal, A., Yadav, H.L., and Pandey, S.S., 2015, Heavy metals from acid mine drainage in coal mines-A case study, Eur. J. Adv. Eng. Technol., 2 (8), 16-20.

[2] Hurtado, C., Viedma, P., and Cotoras, D., 2018, Design of a bioprocess for metal and sulfate removal from acid mine drainage, Hydrometallurgy, 180, 72-77.
[3] Larrson, M., Nosrati, A., Kaur, S., Wagner, J., Baus, U., and Nydén, M., 2017, Copper removal from acid mine drainage-polluted water using glutaraldehydepolyethyleneimine modified diatomaceous earth particles, Heliyon, 4 (2), e00520.

[4] Park, I., Tabelin, C.B., Jeon, S., Li, X., Seno, K., Ito, M., and Hiroyosi, N., 2019, A review of recent strategies for acid mine drainage prevention and mine tailings recycling, Chemosphere, 219, 588-606.

[5] Najib, T., Solgi, M., Farazmand, A., Heydarian, S.Y., and Nasernejad, B., 2017, Optimization of sulfate removal by sulfate reducing bacteria using response surface methodology and heavy metal removal in a sulfidogenic UASB reactor, J. Environ. Chem. Eng., 5 (4), 3256-3265.

[6] Kumar, A., Bisht, B.S., Josdhi, V.D., and Dhewa, T., 2011, Review on bioremediation of polluted environment: A management tool, Int. J. Environ. Sci., 1 (16), 1079-1093.

[7] Benedetto, J.S., de Almeida, S.K., Gomes, H.A., Vazoller, R.F., and Ladeira, A.C.Q., 2005, Monitoring of sulfate-reducing bacteria in acid water from uranium mines, Min. Eng., 18 (13-14), 1341-1343.

[8] Gadd, G.M., and White, C., 1993, Microbial treatment of metal pollution-A working biotechnology?, Trends Biotechnol., 11 (8), 353-359.

[9] de Aquino, S., Fuess, L.T., and Pires, E.C., 2017, Media arrangement impacts cell growth in anaerobic fixed-bed reactors treating sugarcane vinasse: Structured vs. randomic biomass immobilization, Bioresour. Technol., 235, 219-228.

[10] Kousi, P., Remoundaki, E., Hatzikioseyian, A., Battaglia-Brunet, F., Joulian, C., Kousteni, V., and Tsezos, M., 2011, Metal precipitation in an ethanolfed, fixed-bed sulphate-reducing bioreactor, $J$. Hazard. Mater., 189 (3), 677-684.

[11] Pandey, S., and Sarkar, S., 2017, Anaerobic treatment of wastewater using a two-stage packedbed reactor containing polyvinyl alcohol gel beads as biofilm carrier, J. Environ. Chem. Eng., 5 (2), 1575-1585.

[12] Kumar, G., and Buitrón, G., 2017, Fermentative biohydrogen production in fixed bed reactors using 
ceramic and polyethylene carriers as supporting material, Energy Procedia, 142, 743-748.

[13] Muri, P., Marinšek-Logar, R., Djinović, P., and Pintar, A., 2018, Influence of support materials on continuous hydrogen production in anaerobic packed-bed reactor with immobilized hydrogen producing bacteria at acidic condition, Enzyme Microb. Technol., 111, 87-96.

[14] Zheng, H., Li, D., Stanislaus, M.S., Zhang, N., Zhu, Q., Hu, X., and Yang, Y., 2015, Development of a biozeolite fixed-bed bioreactor for mitigating ammonia inhibition of anaerobic digestion with extremely high ammonium concentration livestock waste, Chem. Eng. J., 280, 106-114.

[15] Chen, W.S., Tsai, C.Y., Chen, S.Y., Sung, S., and Lin, J.G., 2019, Treatment of campus domestic wastewater using ambient-temperature anaerobic fluidized membrane bioreactors with zeolites as carriers, Int. Biodeterior. Biodegrad., 136, 49-54.

[16] Retnaningrum, E., and Wilopo, W., 2017, Removal of sulphate and manganese on synthetic wastewater in sulphate reducing bioreactor using Indonesian natural zeolite, Indones. J. Chem., 17 (2), 203-210.

[17] Encina, P.A.G., and Hidalgo, M.D., 2005, Influence of substrate feed patterns on biofilm development in anaerobic fluidized bed reactors (AFBR), Process Biochem., 40 (7), 2509-2516.

[18] Sheoran, A.S., Sheoran, V., and Choudhary, R.P., 2010, Bioremediation of acid-rock drainage by sulphate-reducing prokaryotes: A review, Miner. Eng., 23 (14), 1073-1100.

[19] Zhang, M., Wang, H., and Han, X., 2016, Preparation of metal-resistant immobilized sulfate reducing bacteria beads for acid mine drainage treatment, Chemosphere, 154, 215-223.

[20] Ahmad, M., Liu, S., Mahmood, N., Mahmood, A., Ali, M., Zheng, M., and Ni, J., 2017, Effects of porous carrier size on biofilm development, microbial distribution and nitrogen removal in microaerobic bioreactors, Bioresour. Technol., 234, 360-369.

[21] Wijesinghe, D.T.N., Dassanayake, K.B., Scales, P.J., Sommer, S.G., and Chen, D., 2018, Effect of Australian zeolite on methane production and ammonium removal during anaerobic digestion of swine manure, J. Environ. Chem. Eng., 6 (1), 1233-1241.

[22] Kaksonen, A.H., Plumb, J.J., Robertson, W.J., Vanhanen, M.R., Franzman, P.D., and Puhakka, J.A., 2006, The performance, kinetics and microbiology of sulfidogenic fluidized-bed treatment of acidic metal- and sulfate-containing wastewater, Hydrometallurgy, 83 (1-4), 204-213.

[23] Gupta, G.N., Srivastava, S., Khare, S.K., and Prakash, V., 2014, Extremophiles: An overview of microorganism from extreme environment, Int. J. Agric. Environ. Biotechnol., 7 (2), 371-380.

[24] Kolmert, Å., Wikström, P., and Hallberg, K.B., 2000, A fast and simple turbidimetric method for the determination of sulfate in sulfate-reducing bacterial cultures, J. Microbiol. Methods, 41 (3), 179-184.

[25] Postgate, J.R., 1984, The Sulphate Reducing Bacteria, $2^{\text {nd }}$ Ed., University Press, Cambridge, UK, 20-30.

[26] Cardell, C., and Guerra, I., 2016, An overview of emerging hyphenated SEM-EDX and Raman spectroscopy systems: Applications in life, environmental and materials sciences, $\operatorname{Tr} A C$, Trends Anal. Chem., 77, 156-166.

[27] Cabrera, G., Pérez, R., Gómez, J.M., Abalos, A., and Cantero, D., 2006, Toxic effects of dissolved heavy metals on Desulfovibrio vulgaris and Desulfovibrio sp. strains, J. Hazard. Mater., 135 (1-3), 40-46.

[28] Chen, J., Wang, R., Wang, X., Chen, Z., Feng, X., and Qin, M., 2019, Response of nitrification performance and microbial community structure in sequencing biofilm batch reactors filled with different zeolite and alkalinity ratio, Bioresour. Technol., 273, 487-495.

[29] Song, Z., Zhang, X., Ngo, H.H., Guo, W., Song, P., Zhang, Y., Wen, H., and Guo, J., 2019, Zeolite powder based polyurethane sponges as biocarriers in moving bed biofilm reactor for improving nitrogen removal of municipal wastewater, Sci. Total Environ., 651 (1), 1078-1086.

[30] Li, R., Liu, D., Zhang, Y., Zhou, J., Tsang, Y.F., Liu, Z., Duan, N., and Zhang, Y., 2019, Improved methane production and energy recovery of post hydrothermal liquefaction waste water via 
integration of zeolite adsorption and anaerobic digestion, Sci. Total Environ., 651 (1), 61-69.

[31] Janyasuthiwong, S., Rene, E.R., Esposito, G., and Lens, P.N.L., 2015, Effect of pH on Cu, Ni and Zn removal by biogenic sulfide precipitation in an inversed fluidized bed bioreactor, Hydrometallurgy, 158, 94-100.

[32] Welch, K., Cai, Y., and Strømme, M.A., 2012, Method for quantitative determination of biofilm viability, J. Funct. Biomater., 3 (2), 418-431.

[33] Retnaningrum, E., and Wilopo, W., 2016, Performance and bacterial composition of anodic biofilms in microbial fuel cell using dairy wastewater, AIP Conf. Proc., 1744 (1), 020018.

[34] Martins, M.M., Faleirob, L., Barros, R.J., Veríssimo, A.R., Barreiros, M.A., and Costa, C.M., 2009, Characterization and activity studies of highly heavy metal resistant sulphate reducing bacteria to be used in acid mine drainage decontamination, J. Hazard. Mater, 166 (2-3), 706-713.

[35] Miran, W., Jang, J., Nawaz, M., Shahzad, A., Jeong, S.E., Jeon, C.O., and Lee, D.S., 2017, Mixed sulfatereducing bacteria-enriched microbial fuel cells for the treatment of wastewater containing copper,
Chemosphere, 189, 134-142.

[36] Raj, K.K., Sardar, U.S., Bhargavi, E., Devi, I., Bhunia, B., and Tiwari, O.N., 2018, Advances in exopolysaccharides based bioremediation of heavy metals in soil and water: A critical review, Carbohydr. Polym., 199, 353-364.

[37] Bratkova, S., Koumanova, B., and Beschkov, V., 2013, Biological treatment of mining wastewaters by fixed-bed bioreactors at high organic loading, Bioresour. Technol., 137, 409-413.

[38] Hullesbusch, E.D., Zandvoort, M.H., and Lens, P.N.L., 2003, Metal immobilisation by biofilms: Mechanisms and analytical tools, Rev. Environ. Sci. Biotechnol, 2 (1), 9-33.

[39] White, C., and Gad, G.M., 2000, Copper accumulation by sulfate-reducing bacterial biofilms, FEMS Microbiol. Lett., 183 (2), 313-318.

[40] Kiran, M.G., Pakshirajan, K., and Das, G., 2017, Heavy metal removal from multicomponent system by sulfate reducing bacteria: Mechanism and cell surface characterization, J. Hazard. Mater., 324, 62-70.

[41] Chang, J.C., 1993, "Solubility product constants" in CRC Hand Book of Chemistry and Physics, Eds. Lide, D.R., CRC Press, Boca Raton, 8-39. 